\title{
Possibilities of chemical control of anthracnose (Colletotrichum spp.) in lupine crop
}

\author{
Możliwości ograniczania antraknozy (Colletotrichum spp.) \\ w uprawie łubinu przy użyciu fungicydów
}

\author{
Joanna Horoszkiewicz-Janka*, Marek Korbas, Ewa Jajor, Jakub Danielewicz
}

Summary

The implementation of direct subsidies for legumes in recent years is one of the main factors causing growth of the area of, among others, lupine crops in Poland. Occurrence of diseases, including anthracnose, which is dangerous for lupine, reduces the quantity and quality of crops. There are only two active substances (thiophanate methyl and chlorothalonil) registered for spray application to control the symptoms of anthracnose during the vegetation season. In order to check the possibilities of reducing the severity of anthracnose symptoms and the growth of Colletotrichum spp. - the perpetrators of the disease, field and laboratory experiments were carried out. In studies with yellow and narrow-leaved lupine, the possibilities of using fungicides belonging to chemical groups other than previously registered fungicides were determined. Preparations containing such active substances as picoxystrobin and tebuconazole reduced the occurrence of anthracnose symptoms on yellow lupine in a year with very high disease pressure. Under in vitro conditions Colletotrichum spp. growth was limited the most by the active substances such as prochloraz, picoxystrobin and tebuconazole.

Key words: lupine, diseases, anthracnose, fungicides, crop

\section{Streszczenie}

Wprowadzenie dopłat bezpośrednich do uprawy roślin bobowatych jest jednym z czynników powodujących wzrost areału uprawy m.in. łubinów. Występowanie chorób, w tym groźnej dla łubinów antraknozy, wpływa na obniżenie ilości i jakości plonu. Do ograniczenia nasilenia objawów tej choroby w uprawie łubinu zarejestrowane są dwie substancje czynne - tiofanat metylowy i chlorotalonil, które mogą być stosowane w zabiegu ochrony roślin w okresie wegetacji. W celu sprawdzenia możliwości ograniczania nasilania objawów antraknozy oraz wzrostu Colletotrichum spp. - sprawców choroby, przeprowadzono doświadczenia polowe oraz laboratoryjne. W badaniach z łubinem żółtym i wąskolistnym określano możliwości zastosowania fungicydów należących do grup chemicznych, innych niż dotychczas zarejestrowane fungicydy. Preparaty zawierające takie substancje czynne, jak: pikoksystrobina i tebukonazol ograniczały występowanie objawów antraknozy na łubinie żółtym w roku o bardzo silnej presji choroby. W warunkach in vitro substancje czynne: prochloraz, pikoksystrobina i tebukonazol najlepiej hamowały wzrost Colletotrichum spp.

Słowa kluczowe: łubin, choroby, antraknoza, fungicydy, plon

\author{
Instytut Ochrony Roślin - Państwowy Instytut Badawczy \\ Zakład Mykologii \\ Władysława Węgorka 20, 60-318 Poznań \\ *corresponding author: j.horoszkiewicz@iorpib.poznan.pl \\ ORCID: 0000-0002-2964-4593
}




\section{Wstęp / Introduction}

W ostatnich latach nastąpił wzrost areału uprawy roślin bobowatych w Polsce. Udział roślin bobowatych na nasiona (bez soi) w strukturze zasiewów ogółem wynosił w: 2004 r. - 1,0\%, a w 2017 r. - 2,5\% (Księżak 2015). Powolna odbudowa areału upraw, po załamaniu produkcji roślin bobowatych w latach dziewięćdziesiątych ubiegłego wieku, związana jest z realizacją programów rolnośrodowiskowych, a aspekty agrotechniczne i ekonomiczne wskazują na możliwość dalszego zwiększania areału uprawy roślin bobowatych na obszarze Polski (Florek i wsp. 2012; Adamska i wsp. 2016).

Wraz ze wzrostem areału łubinów może wzrastać ryzyko występowania chorób. Średnio wysokość strat plonu nasion spowodowanych występowaniem chorób w uprawie łubinu szacuje się na 10-15\%, chociaż niekiedy są one znacznie wyższe i lokalnie mogą wynosić nawet 90\% (Krawczyk i Mrówczyński 2012). Objawy chorobowe w uprawie łubinów mogą występować od fazy kiełkowania (BBCH 01) do końca rozwoju strąków i nasion (BBCH 79). W fazie kwitnienia (BBCH 60-69) rośliny są szczególnie wrażliwe na porażenie przez grzyby. Jedną z groźnych chorób łubinu, która stwarza duże zagrożenie dla wielkości oraz jakości uzyskanego plonu, jest antraknoza łubinu powodowana przez grzyby: Colletotrichum lupini i Colletotrichum gloeosporioides. Po epidemicznym wystąpieniu choroby na przełomie XX i XXI wieku drastycznie zmalał areał uprawy łubinu białego (Gresta i wsp. 2017). Wadą tego gatunku jest znaczna wrażliwość na porażenie przez sprawców antraknozy. O znacznej deprecjacji tego gatunku w naszym kraju świadczy fakt, że od 1996 roku odmiany łubinu białego wpisuje się do krajowego rejestru bez sprawdzania ich wartości gospodarczej (Prusiński 2015). Obecnie antraknoza występuje najczęściej w uprawie łubinu żółtego (Bilski i Kajdan-Zysnarska 2016). Odmiany łubinu wąskolistnego są mniej wrażliwe na porażenie przez Colletotrichum spp. Według badań COBORU (2018) średni stopień porażenia dla odmian łubinu wąskolistnego wynosił 8,8 , a dla łubinu żółtego wynosił 8,4 (w II terminie obserwacji) i odpowied- nio 8,6 dla łubinu wąskolistnego i 7,0 dla łubinu żółtego w III terminie obserwacji. Liczne próby wyhodowania form odpornych na tą chorobę nie powiodły się (Frencel i wsp. 2000). W Polsce duże nadzieje można wiązać z identyfikacją kilku linii łubinu białego mniej podatnych na antraknozę, które mogą być w przyszłości źródłem genetycznej odporności na Colletotrichum spp. nowych odmian (Rybiński i wsp. 2014). Praktyka rolnicza wskazuje jednak, że bez możliwości zastosowania fungicydów, skuteczne ograniczanie nasilenia objawów choroby jest trudne (Horoszkiewicz-Janka i wsp. 2012). Obecnie do zwalczania Colletotrichum spp. zarejestrowane są fungicydy do stosowania w trakcie wegetacji, w skład których wchodzą następujące substancje czynne (s.cz.): tiofanat metylowy - substancja o działaniu układowym z grupy chemicznej benzimidazoli, która może być stosowana od początku fazy rozwoju pędów bocznych łubinu (BBCH 21) oraz chlorotalonil - substancja o działaniu powierzchniowym, którą można stosować od fazy kwitnienia (BBCH 55) (Korbas i wsp. 2018). Zgodnie z rozporządzeniem wykonawczym Komisji (UE) 2019/677 s.cz. chlorotalonil została wycofana ze stosowania w krajach Unii Europejskiej, a producenci rolni mają czas na zużycie zapasów do 20 maja 2020 roku (Rozporządzenie 2019). Oznacza to, że jedyną s.cz. do zwalczania antraknozy w 2021 roku będzie tiofanat metylowy.

Celem pracy było określenie możliwości zastosowania fungicydów należących do innych grup chemicznych, niż dotychczas zarejestrowane do ograniczania występowania antraknozy łubinu.

\section{Materiały i metody / Materials and methods}

\section{Doświadczenie polowe}

W latach 2012-2013 na terenie Polowej Stacji Doświadczalnej Instytutu Ochrony Roślin - Państwowego Instytutu Badawczego w Winnej Górze przeprowadzono ścisłe doświadczenia polowe. Materiał badawczy stanowił łubin wąskolistny odmiany Regent i łubin żółty odmiany Parys.

Tabela 1. Fungicydy zastosowane $\mathrm{w}$ doświadczeniu

Table 1. Fungicides applied in the experiment

\begin{tabular}{|c|c|c|c|c|}
\hline $\begin{array}{l}\text { Lp. } \\
\text { No. }\end{array}$ & $\begin{array}{c}\text { Substancja czynna } \\
\text { Active substance } \\
{[\mathrm{g} / \mathrm{l}]} \\
\end{array}$ & $\begin{array}{l}\text { Fungicyd } \\
\text { Fungicide }\end{array}$ & $\begin{array}{l}\text { Grupa chemiczna } \\
\text { Chemical group }\end{array}$ & $\begin{array}{c}\text { Dawka - Dose } \\
{[1 / \mathrm{ha}]}\end{array}$ \\
\hline 1. & kontrola-control & - & - & - \\
\hline 2. & picoxystrobin (250) & Acanto $250 \mathrm{SC}$ & strobiluryny - strobilurins & 1,0 \\
\hline 3. & prochloraz (450) & Atak $450 \mathrm{EC}$ & imidazole - imidazoles & 1,0 \\
\hline 4. & tebuconazole (250) & Sparta $250 \mathrm{EW}$ & triazole - triazoles & 1,0 \\
\hline 5. & $\begin{array}{l}\text { tiophanate methyl (233), } \\
\text { tetraconazole }(70)\end{array}$ & Yamato $303 \mathrm{SE}$ & $\begin{array}{l}\text { benzimidazole, triazole } \\
\text { benzimidazoles, triazoles }\end{array}$ & 1,5 \\
\hline
\end{tabular}

Źródło: Etykiety fungicydów (http://www.bip.minrol.gov.pl), Turner (2015) 
W fazie kwitnienia (BBCH 55) wykonano zabiegi opryskiwania przy użyciu fungicydów (tab. 1). Trzy tygodnie po przeprowadzeniu zabiegów określono porażenie roślin (procent porażonych strąków) i ocenę fitotoksyczności zastosowanych środków. Określono również plon nasion oraz masę tysiąca nasion. Uzyskane wyniki poddano analizie statystycznej.

\section{Doświadczenie laboratoryjne}

Do badań wybrano 3 izolaty (nr I, nr II, nr III) Colletotrichum spp. wyizolowane $\mathrm{z}$ porażonych roślin łubinu, pochodzące z różnych miejscowości województwa wielkopolskiego. W doświadczeniu użyto pięć substancji czynnych (Sigma Aldrich) fungicydów, które stosowano w doświadczeniu polowym w dwóch stężeniach (tab. 2). Badane substancje czynne dodawano do sterylnej pożywki PDA (Potato Dextrose Agar), w ilości pozwalającej na uzyskanie stężeń: 0,1 i 0,5 ppm. Kontrolę stanowiła pożywka bez dodatku substancji czynnej. Pożywkę rozlewano na płytki Petriego o średnicy $90 \mathrm{~mm}$, a następnie wykładano na nią krążki PDA przerośnięte grzybnią patogena. Doświadczenie przeprowadzono w 2 seriach, każdorazowo w 3 powtórzeniach $\mathrm{i}$ inkubowano w temperaturze $20^{\circ} \mathrm{C}$ przez 14 dni. Ocenę wykonano mierząc liniowy wzrost grzybni. Procent hamowania wzrostu grzybni obliczono w odniesieniu do kontroli.

\section{Wyniki i dyskusja / Results and discussion}

W 2012 roku łubin żółty był silniej porażony przez Colletotrichum spp., aniżeli łubin wąskolistny. Odmiana łubinu wąskolistnego Regent w badaniach Podleśnego i wsp. (2016) wykazywała najmniejszą wrażliwość na porażenie przez Colletotrichum spp. spośród 16 badanych odmian łubinu wąskolistnego. W badaniach z łubinem żółtym, Podleśny i Podleśna (2014) wykazali, że odmiana Parys była najmniej odporna na porażenie przez Colletotrichum
Tabela 2. Substancje czynne zastosowane w doświadczeniu in vitro Table 2. Active substances of fungicides applied in the in vitro experiment

\begin{tabular}{l|c}
\hline $\begin{array}{c}\text { Substancja czynna } \\
\text { Active substance }\end{array}$ & $\begin{array}{c}\text { Grupa chemiczna } \\
\text { Chemical group }\end{array}$ \\
\hline Picoxystrobin & strobiluryny - strobilurins \\
\hline Prochloraz & imidazole - imidazoles \\
\hline Tebuconazole & triazole - triazoles \\
\hline Tetraconazole & triazole - triazoles \\
\hline Tiophanate methyl & benzimidazole - benzimidazoles \\
\hline
\end{tabular}

Źródło: Turner (2015), Korbas i wsp. (2017)

spp. Poza antraknozą, w pierwszym roku badań zanotowano wystapienie w łubinie wąskolistnym odmiany Regent fuzaryjnego więdnięcia łubinu (Fusarium oxysporum). W drugim roku badań średni procent porażenia strąków przez Colletotrichum spp. był taki sam na obu badanych odmianach łubinu. Na podstawie łodyg łubinu żółtego odmiany Parys występowały także objawy rizoktoniozy (Rhizoctonia solani).

Średni udział porażonych strąków z lat dla kombinacji kontrolnej łubinu wąskolistnego wynosił 6,7\%, a dla łubinu żółtego 8,0\% (tab. 4). Większy udział objawów antraknozy łubinu odnotowano w 2012 roku i wynosił on średnio 7,3\% porażonych strąków łubinu żółtego oraz 4,5\% łubinu wąskolistnego. Nasilenie objawów choroby spowodowane było obfitymi opadami deszczu w czerwcu i lipcu 2012 roku (powyżej $90 \mathrm{~mm}$ ) (tab. 3).

Zastosowanie chemicznej ochrony roślin spowodowało istotne obniżenie udziału strąków z objawami choroby po aplikacji większości fungicydów. Nie stwierdzono fitotoksycznego działania badanych fungicydów na rośliny łubinu. Zastosowanie w łubinie wąskolistnym wszystkich badanych fungicydów w 2012 roku, a w 2013 roku z wyjątkiem środków zawierających prochloraz oraz tiofanat metylowy

Tabela 3. Warunki meteorologiczne w trakcie prowadzenia doświadczeń (Winna Góra) Table 3. Meteorogical data during conduct experiments (Winna Góra)

\begin{tabular}{|c|c|c|c|c|c|c|c|}
\hline \multirow{2}{*}{$\begin{array}{c}\text { Parametry pogody } \\
\text { Weather data }\end{array}$} & \multirow{2}{*}{$\begin{array}{c}\text { Sezon } \\
\text { Season }\end{array}$} & \multicolumn{6}{|c|}{ Miesiąc - Month } \\
\hline & & IV & $\mathrm{V}$ & VI & VII & VIII & IX \\
\hline \multirow{2}{*}{$\begin{array}{l}\text { Średnia temperatura } \\
\text { Mean temperature } \\
{\left[{ }^{\circ} \mathrm{C}\right]}\end{array}$} & 2012 & 8,90 & 16,00 & 16,71 & 19,91 & 19,08 & 14,51 \\
\hline & 2013 & 8,67 & 15,10 & 17,93 & 19,99 & 17,09 & 13,01 \\
\hline \multirow{2}{*}{$\begin{array}{l}\text { Suma opadów } \\
\text { Rainfalls } \\
{[\mathrm{mm}]}\end{array}$} & 2012 & 21,30 & 31,50 & 94,00 & 98,90 & 36,30 & 66,90 \\
\hline & 2013 & 21,60 & 89,20 & 82,50 & 41,00 & 9,70 & 106,20 \\
\hline \multirow{2}{*}{$\begin{array}{l}\text { Wilgotność } \\
\text { Humidity } \\
{[\%]}\end{array}$} & 2012 & 68,57 & 64,55 & 77,64 & 78,04 & 76,26 & 80,67 \\
\hline & 2013 & 71,44 & 72,95 & 80,11 & 78,30 & 71,48 & 81,68 \\
\hline
\end{tabular}


+ tetrakonazol, spowodowało statystycznie istotne zmniejszenie odsetka porażonych strąków (tab. 4). Na łubinie żółtym w 2012 roku występowanie antraknozy skutecznie ograniczyło zastosowanie preparatów zawierających s.cz.: pikoksystrobinę oraz tiofanat metylowy + tetrakonazol. W 2013 roku wszystkie zastosowane fungicydy wpłynęły na obniżenie porażenia przez Colletotrichum spp. Analizując wyniki średnich z lat obserwacji, wszystkie zastosowane fungicydy istotnie ograniczały udział porażonych strąków.

Stwierdzono istotnie większą masę tysiąca nasion (MTN) łubinu wąskolistnego zebranych w 2012 roku po zastosowaniu s.cz. tebukonazol oraz łubinu żółtego po zastosowaniu s.cz. pikoksystrobina, prochloraz oraz tiofanat metylowy + tetrakonazol. Biorąc pod uwagę średnią z lat, zastosowanie fungicydu zawierającego pikoksystrobinę istotnie wpłynęło na wzrost MTN (tab. 5). Istotny wzrost plonu łubinu żółtego odmiany Parys, zanotowano po zastosowaniu w 2012 roku fungicydu zawierającego s.cz. pikoksystrobinę (tab. 6). W badaniach, w których porów- nywano plonowanie 8 odmian łubinu żółtego uprawianych w 12 różnych lokalizacjach Polski, autorzy zanotowali najsłabsze plony odmiany Parys. Średnio wynosiły one 12,7 dt/ha (Podleśny i Podleśna 2014). W badaniach własnych plony łubinu żółtego wynosiły od 17,3 do 25,5 dt/ha. Zastosowanie w 2012 roku fungicydów zawierających s.cz. pikoksystrobinę oraz tiofanat metylowy + tetrakonazol istotnie wpłynęło na zwiększenie plonowania również łubinu wąskolistnego. Warto podkreślić, iż istotnie większe plony uzyskano w 2012 roku, w którym udział porażonych strąków był większy. Suma opadów w 2012 i 2013 roku była zbliżona i wynosiła odpowiednio, 348,9 i 350,5 mm. Suma opadów w lipcu 2012 roku była jednak dwukrotnie wyższa niż w 2013 roku, a w sierpniu 2012 roku ponad trzykrotnie niż w 2013 roku. Wskazuje to na wpływ rozkładu opadów w okresie wegetacji łubinu na występowanie objawów antraknozy na strąkach.

Procent hamowania wzrostu grzybni (in vitro) wzrastał wraz ze wzrostem stężenia s.cz. w pożywce (tab. 7). Wzrost

Tabela 4. Procent strąków łubinu wąskolistnego i żółtego z objawami antraknozy

Table 4. Percent of narrow-leaved and yellow lupin pods infected with anthracnose symptoms

\begin{tabular}{|c|c|c|c|c|c|c|}
\hline \multirow{2}{*}{$\begin{array}{l}\text { Substancja czynna }[\mathrm{g} / 1] / \text { Lata } \\
\text { Active substance }[\mathrm{g} / 1] / \text { Years }\end{array}$} & \multicolumn{3}{|c|}{$\begin{array}{l}\text { Łubin wąskolistny } \\
\text { Narrow-leaved lupin }\end{array}$} & \multicolumn{3}{|c|}{$\begin{array}{l}\text { Łubin żółty } \\
\text { Yellow lupin }\end{array}$} \\
\hline & 2012 & 2013 & $\begin{array}{l}\text { średnio } \mathrm{z} \text { lat } \\
\text { mean }\end{array}$ & 2012 & 2013 & $\begin{array}{l}\text { średnio } \mathrm{z} \text { lat } \\
\text { mean }\end{array}$ \\
\hline Średnio $\mathrm{z}$ lat - Years average & 4,5 & 2,4 & 3,5 & 7,3 & 2,4 & 4,9 \\
\hline Kontrola - Control & 8,2 & 5,2 & 6,7 & 10,4 & 5,6 & 8,0 \\
\hline Picoxystrobin (250) & 3,2 & 0,5 & 1,9 & 3,6 & 0,5 & 2,1 \\
\hline Prochloraz (450) & 4,2 & 3,0 & 3,6 & 8,7 & 1,7 & 5,2 \\
\hline Tebuconazole (250) & 3,5 & 0,6 & 2,1 & 8,2 & 1,6 & 4,9 \\
\hline $\begin{array}{l}\text { Tiophanate methyl (233), } \\
\text { tetraconazole (70) }\end{array}$ & 3,6 & 2,9 & 3,3 & 5,6 & 2,6 & 4,1 \\
\hline NIR $(0,05)-\operatorname{LSD}(0.05)$ & 3,274 & 2,915 & 2,076 & 3,025 & 2,223 & 1,954 \\
\hline
\end{tabular}

Tabela 5. Masa tysiąca nasion łubinu wąskolistnego i żółtego [g]

Table 5. Weight of thousand grain of narrow-leaved and yellow lupin [g]

\begin{tabular}{|c|c|c|c|c|c|c|}
\hline \multirow{2}{*}{$\begin{array}{l}\text { Substancja czynna }[\mathrm{g} / 1] / \text { Lata } \\
\text { Active substance }[\mathrm{g} / 1] / \text { Years }\end{array}$} & \multicolumn{3}{|c|}{$\begin{array}{l}\text { Łubin wąskolistny } \\
\text { Narrow-leaved lupin }\end{array}$} & \multicolumn{3}{|c|}{$\begin{array}{l}\text { Łubin żółty } \\
\text { Yellow lupin }\end{array}$} \\
\hline & 2012 & 2013 & $\begin{array}{l}\text { średnio z lat } \\
\text { mean }\end{array}$ & 2012 & 2013 & $\begin{array}{l}\text { średnio } \mathrm{z} \text { lat } \\
\text { mean }\end{array}$ \\
\hline Średnio z lat - Years average & 138,7 & 117,4 & 128,1 & 140,9 & 131,3 & 136,1 \\
\hline Kontrola - Control & 137,5 & 118,9 & 128,2 & 137,2 & 130,5 & 133,9 \\
\hline Picoxystrobin (250) & 134,7 & 115,4 & 125,0 & 143,2 & 138,4 & 140,8 \\
\hline Prochloraz (450) & 138,9 & 117,3 & 128,1 & 145,2 & 129,6 & 137,4 \\
\hline Tebuconazole (250) & 144,2 & 117,9 & 131,1 & 138,6 & 131,8 & 135,2 \\
\hline $\begin{array}{l}\text { Tiophanate methyl (233), } \\
\text { tetraconazole ( } 70)\end{array}$ & 138,3 & 117,7 & 127,9 & 140,2 & 126,2 & 133,2 \\
\hline $\operatorname{NIR}(0,05)-\operatorname{LSD}(0.05)$ & 4,273 & r.n. & r.n. & 3,011 & r.n. & 6,271 \\
\hline
\end{tabular}

r.n. - różnice nieistotne - not significant differences 
Tabela 6. Plon nasion łubinu wąskolistnego i żółtego [t/ha]

Table 6. Seed yield of narrow-leaved and yellow lupin [t/ha]

\begin{tabular}{l|c|c|c|c|c|c}
\hline \multirow{2}{*}{$\begin{array}{l}\text { Substancja czynna [g/l]/Lata } \\
\text { Active substance [g/l]/Years }\end{array}$} & \multicolumn{3}{|c|}{$\begin{array}{c}\text { Lubin wąskolistny } \\
\text { Narrow-leaved lupin }\end{array}$} & \multicolumn{3}{c}{$\begin{array}{c}\text { Eubin żólty } \\
\text { Yellow lupin }\end{array}$} \\
\cline { 2 - 8 } & 2012 & 2013 & $\begin{array}{c}\text { średnio z lat } \\
\text { mean }\end{array}$ & 2012 & 2013 & $\begin{array}{c}\text { średnio z lat } \\
\text { mean }\end{array}$ \\
\hline Średnio z lat - Years average & 3,00 & 2,27 & 2,63 & 2,41 & 2,00 & 2,20 \\
\hline Kontrola - Control & 2,25 & 2,30 & 2,27 & 2,25 & 1,73 & 1,99 \\
\hline Picoxystrobin (250) & 3,95 & 2,35 & 3,15 & 2,55 & 1,73 & 2,14 \\
\hline Prochloraz (450) & 2,93 & 2,40 & 2,66 & 2,48 & 2,10 & 2,29 \\
\hline Tebuconazole (250) & 2,44 & 2,10 & 2,27 & 2,33 & 2,25 & 2,29 \\
\hline Tiophanate methyl (233), & 3,58 & 2,20 & 2,89 & 2,45 & 2,19 & 2,32 \\
\hline tetraconazole (70) & 1,003 & r.n. & 0,502 & 0,294 & r.n. & r.n. \\
\hline NIR (0,05) - LSD (0.05) & & & & &
\end{tabular}

r.n. - różnice nieistotne - not significant differences

Tabela 7. Wpływ stosowania substancji czynnych w stężeniach 0,1 i 0,5 ppm na hamowanie wzrostu Colletotrichum spp. Table 7. Influence of selected active substances applied in 0.1 and $0.5 \mathrm{ppm}$ on inhibition of Colletotrichum spp. growth

\begin{tabular}{|c|c|c|c|c|c|c|c|c|c|c|}
\hline \multirow{3}{*}{$\begin{array}{c}\text { Nr izolatu } \\
\text { No. of } \\
\text { isolate }\end{array}$} & \multicolumn{10}{|c|}{$\begin{array}{l}\text { Hamowanie wzrostu grzybni - Inhibition of mycelium growth } \\
{[[\%]}\end{array}$} \\
\hline & \multicolumn{2}{|c|}{ picoxystrobin } & \multicolumn{2}{|c|}{ prochloraz } & \multicolumn{2}{|c|}{ tiophanate methyl } & \multicolumn{2}{|c|}{ tebuconazole } & \multicolumn{2}{|c|}{ tetraconazole } \\
\hline & $0,1 \mathrm{ppm}$ & $0,5 \mathrm{ppm}$ & $0,1 \mathrm{ppm}$ & $0,5 \mathrm{ppm}$ & $0,1 \mathrm{ppm}$ & $0,5 \mathrm{ppm}$ & $0,1 \mathrm{ppm}$ & $0,5 \mathrm{ppm}$ & $0,1 \mathrm{ppm}$ & $0,5 \mathrm{ppm}$ \\
\hline I & 33,3 & 52,9 & 42,0 & 54,9 & 10,0 & 19,1 & 39,5 & 54,4 & 21,8 & 31,9 \\
\hline II & 39,3 & 66,7 & 54,0 & 70,7 & 12,8 & 20,8 & 44,1 & 68,8 & 28,4 & 38,2 \\
\hline III & 45,6 & 70,7 & 56,3 & 74,4 & 15,2 & 16,4 & 49,3 & 71,7 & 28,9 & 40,3 \\
\hline $\begin{array}{l}\text { Średnio } \\
\text { Mean }\end{array}$ & 39 & 63 & 51 & 67 & 13 & 19 & 44 & 65 & 26 & 31 \\
\hline
\end{tabular}

trzech izolatów Colletotrichum spp. najsilniej hamowany był przez s.cz. prochloraz w stężeniu 0,5 ppm, średni procent hamowania wzrostu grzybni wynosił w tym przypadku 67. W tym samym stężeniu silnie hamował wzrost grzybni również tebukonazol (65\%) oraz pikoksystrobina (63\%). Natomiast tiofanat metylowy, w obu badanych stężeniach, ograniczał wzrost grzybni w niewielkim stopniu, a średnie ograniczanie wzrostu grzybni wynosiło 13 i 19\%. W badaniach Horoszkiewicz-Janka i wsp. (2017) dotyczących ograniczania wzrostu Colletotrichum spp. zastosowano między innymi tebukonazol. Skuteczność tego środka w stężeniu 0,5 ppm w inhibicji wzrostu czterech izolatów tego taksonu również była wysoka.

\section{Wnioski / Conclusions}

1. Strąki łubinu żółtego wykazywały większą podatność na porażenie przez Colletotrichum spp. w porównaniu z łubinem wąskolistnym.

2. Na łubinie żółtym w warunkach silnej presji grzybów Colletotrichum spp., związanej z większą ilością opadów w czerwcu i lipcu (2012), jedynie preparaty zawierające s.cz. pikoksystrobinę oraz tebukonazol ograniczały udział porażonych strąków. W warunkach atmosferycznych ograniczających zdolności infekcyjne Colletotrichum spp. w 2013 roku wszystkie zastosowane $\mathrm{w}$ doświadczeniu środki ochrony roślin ograniczały udział porażonych strąków.

3. Zastosowane fungicydy w łubinie wąskolistnym, z wyjątkiem fungicydu zawierającego tiofanat metylowy i tetrakonazol (2013 rok), wpłynęły na ograniczenie porażenia strąków przez Colletotrichum spp.

4. Zastosowanie fungicydów wpłynęło na wzrost plonu nasion łubinu żółtego i wąskolistnego.

5. Wzrost grzybni Colletotrichum spp. w warunkach in vitro najsilniej hamowały s.cz.: prochloraz, tebukonazol oraz pikoksystrobina.

6. Ze względu na zjawisko uodpornienia Colletotrichum spp. na stosowane s.cz., wskazane jest zwiększenie liczby substancji czynnych przeznaczonych do zwalczania antraknozy łubinu. 


\section{Literatura / References}

Adamska H., Gniadzik M., Gołąb I., Kozak M. 2016. Opłacalność uprawy wybranych roślin bobowatych. [Production profitability of selected legumes]. Roczniki Naukowe Stowarzyszenie Ekonomistów Rolnictwa i Agrobiznesu 18 (4): 9-13.

Bilski Z., Kajdan-Zysnarska I. 2016. Uprawa roślin grubonasiennych stosowanych w zazielenieniu. Centrum Doradztwa Rolniczego w Brwinowie, Oddział Poznań, 59 ss.

COBORU. 2018. Lista Opisowa Odmian Roślin Rolniczych, Słupia Wielka, 171 ss.

Etykiety fungicydów (http://www.bip.minrol.gov.pl)

Florek J., Czerwińska-Kayzer D., Jerzak M.A. 2012. Aktualny stan i wykorzystanie produkcji upraw roślin strączkowych. [Current state of production and use of leguminous crops]. Fragmenta Agronomica 29 (4): 45-55.

Frencel I., Lewartowska E., Czerwińska A., Nijaki J., Nijaka T. 2000. Poszukiwanie odporności łubinów na chorobę grzybową - antraknozę (Glomerella cingulata/Colletotrichum gloeosporioides). [Screening tests of lupins for resistance to fungal disease anthracnose (Glomerella cingulata/Colletotrichum gloeosporioides)]. Progress in Plant Protection/Postępy w Ochronie Roślin 40 (2): 726-729.

Gresta F., Wink M., Prins U., Abberton M., Capraro J., Scarafoni A., Hill G. 2017. Lupins in European cropping systems. s. 88-108. W: Legumes in Cropping Systems (D. Murphy-Bokern, F.L. Stoddard, C.A. Watson, red.). CABI, Wallingford, UK, 280 ss. ISBN-13: 978-1-78639-178-0.

GUS 2018. Produkcja upraw rolnych i ogrodniczych w 2017 r. Główny Urząd Statystyczny, Warszawa [dostęp online: 7.05.2019].

Horoszkiewicz-Janka J., Jajor E., Korbas M. 2012. Wykorzystanie biopreparatów do zaprawiania nasion roślin strączkowych (bobowe). [Usage of biopreparations as seed dressings in legume cultivation]. Journal of Research and Applications in Agricultural Engineering 57 (3): $162-166$.

Horoszkiewicz-Janka J., Perek A., Korbas M., Jajor E., Danielewicz J., Sobiech Ł. 2017. Ograniczanie wzrostu Colletotrichum lupini przy użyciu wybranych substancji czynnych fungicydów w warunkach in vitro. [Reducing the growth of Colletotrichum lupini with selected active compounds of fungicides in vitro]. Przemysł Chemiczny 96 (6): 1364-1366. DOI: 10.15199/62.2017.6.29

Korbas M., Jajor E., Horoszkiewicz-Janka J., Danielewicz J. 2018. Atlas chorób roślin rolniczych. Wydanie II. Hortpress, Warszawa, 224 ss.

Korbas M., Paradowski A., Węgorek P., Jajor E., Horoszkiewicz-Janka J., Zamojska J., Danielewicz J., Czyczewski M., Dworzańska D. 2017. Vademecum środków ochrony roślin. Wydawnictwo Agronom, Poznań, 676 ss. ISBN 978-83-947740-0-4.

Krawczyk R., Mrówczyński M. (red.). 2012. Metodyka integrowanej ochrony łubinu wąskolistnego, żółtego i białego dla doradców. Instytut Ochrony Roślin - Państwowy Instytut Badawczy, Poznań, 132 ss. ISBN 978-83-89867-86-5.

Księżak J. 2015. Wstęp. s. 5. W: Wybrane zagadnienia uprawy roślin strączkowych (J. Księżak, red.). Fundacja Programów Pomocy dla Rolnictwa FAPA, Warszawa, 69 ss. ISBN 978-83-62282-88-3.

Podleśny J., Podleśna A. 2014. Ocena porażenia roślin łubinu żółtego w różnych rejonach Polski przez patogeny grzybowe. [Evaluation of yellow lupine plant infection by fungal pathogens in different regions of Poland]. Progress in Plant Protection 54 (4): $423-429$. DOI: 10.14199/ppp-2014-072

Podleśny J., Podleśna A., Bieniaszewski T. 2016. Występowanie chorób grzybowych na roślinach łubinu wąskolistnego (Lupinus angustifolius L.) w różnych rejonach Polski. [Occurrence of fungal diseases on blue lupine (Lupinus angustifolius L.) plants at different regions of Poland]. Progress in Plant Protection 56 (1): 25-33. DOI: 10.14199/ppp-2016-004

Prusiński J. 2015. Łubin biały (Lupinus albus L.) - historia udomowienia i postępu biologicznego. [White lupin (Lupinus albus L.) - history of domestication and biological progress]. Zeszyty Problemowe Postępów Nauk Rolniczych 580: 105-119.

Rozporządzenie wykonawcze Komisji (UE) 2019/677 z dnia 29 kwietnia 2019 r. w sprawie nieodnawiania zatwierdzenia substancji czynnej chlorotalonil, zgodnie z rozporządzeniem Parlamentu Europejskiego i Rady (WE) nr 1107/2009 dotyczącym wprowadzania do obrotu środków ochrony roślin, oraz w sprawie zmiany rozporządzenia wykonawczego Komisji (UE) nr 540/2011.

Rybiński W., Święcicki W., Nawrot Cz., Barzyk P., Starzycki M., Starzycka E., Wilczura M. 2014. Zawartość alkaloidów i tłuszczu w nasionach oraz odporność na antraknozę w krajowej kolekcji łubinu białego. Materiały Konferencyjne „Łubin we współczesnym rolnictwie”. Kudowa Zdrój, 8-10 września 2014: 112-113.

Turner J.A. (red.). 2015. The Pesticide Manual: A World Compendium. Seventeenth Edition. British Crop Protection Council, 1440 ss. ISBN-13: 978-1901396881. 